\title{
PROGNOSTICATION OF STORAGE TERMS FOR PASTEURIZED SAUSAGES WITH ACTIVE PACKAGE ELEMENTS
}

\author{
Vasyl Pasichnyi \\ Department of Technology of Meat and Meat Products ${ }^{1}$ \\ Pasww1@ukr.net \\ Oleksandr Shevchenko \\ Vice-Rector 1 \\ Oleg Khrapachov \\ Regional represantative LLC «Sirius Extrusion» \\ 20 Pilotskaya str., Khmelnitsky, Ukraine, 29010 \\ kov.pack@ukr.net \\ Andriy Marynin \\ Problem Research Laboratory ${ }^{1}$ \\ andrii_marynin@ukr.net \\ Irina Radzievskaya \\ Department of Fats, Perfumery and Cosmetic Products Technology ${ }^{1}$ \\ logos2007@ukr.net \\ Yuliia Matsuk \\ Department of Food Technologies \\ Oles Honchar Dnipro National University \\ 8 Kozakova str., Dnipro, Ukraine, 49000 \\ lyly2006@ukr.net \\ Alina Geredchuk \\ Department of food industry technologies and restaurant industry \\ Higher Educational Institution of Ukoopspilka \\ "Poltava University of Economicsand Trade" \\ 3 Koval str., Poltava, Ukraine, 36014 \\ alina-ger13@ukr.net \\ Mikhail Kuligin \\ Department of Chemical Technology, Expertise and Food Safety \\ Kherson National Technical University \\ 24 Berislavskoye shosse, Kherson, Ukraine, 73008 \\ mkuligin@gmail.com \\ ${ }^{1}$ National University of Food Technologies \\ 68 Volodumurska str., Kyiv, Ukraine, 01601
}

\footnotetext{
Abstract

The work is devoted to optimization modeling of an influence of pasteurization with oxygen absorbers on spoilage processes of lipids of boiled sausage products. According to the results, the influence on changes of peroxide and acid numbers of lipids of small sausages, pasteurized at presence of an oxygen absorber, has been mathematically prognosticated.

At mathematical modeling, mathematic packages MathCad and «Data analysis» (ET) MSExcel were used. The experiment was planned according to the plan of full factorial experiment.

The dependence as to the influence of the recipe composition of sausage products at their storage on peroxide and acid number values has been revealed.

The conducted modeling allows to state the adequacy of obtained regressive equations. The obtained empirical dependencies allow to prognosticate a storage term of boiled sausages products, pasteurized with elements of active package at using protecting barrier multi-layer polymeric materials.
} 
The optimization modeling was conducted by structuring a mathematical model as an analytic expression that reflects the connection of factor signs with a parametric index. The obtained response functions are adequate and have a high correspondence to real experimental data.

Storage terms were substantiated for small sausages, which recipe included beef, pork, poultry meat and also food emulsions, based on animal proteins. The process of repeated pasteurization was conducted at temperature $85-90{ }^{\circ} \mathrm{C}$ during $15-20$ minutes.

Keywords: small sausages, sorts, pasteurization, lipids spoilage, active package.

DOI: $10.21303 / 2504-5695.2020 .001376$

\section{Introduction}

Providing quality and safety of sausage products at their storage depends on observing the production technology and storage conditions [1, 2].

The presence of specific microflora may accelerate spoilage processes and needs observance of the initial control of raw materials, search for methods of stabilizing microbiological contamination at production and storage stages $[1,3,4]$.

Important factors of safety provision of sausage products are a counteraction to accumulation of peroxide (PN) and acid (AN) numbers that determine lipids spoilage $[5,6]$. The process of lipids spoilage is one of criteria that determine the consumption appropriateness term of products $[7,8]$.

Thus, prognostication of the process of lipids spoilage at using antioxidants and modern packing technologies, including ones for pasteurized sausage products, is an urgent question that needs scientific substantiation [8].

\section{Problem review}

Most studies for prolonging storage terms with using high-barrier package materials and active packing elements are aimed at improving products protection from external factors [4, 5]. A choice of rational ways of thermal processing [8], and use of methods of increasing microbiological stability of raw materials remain urgent [7].

System analysis, optimization modeling as to estimating the influence of raw materials on products quality and safety are used in scientific works [9]. A factor space for most studies is taking into account raw material types, methods and regimes of thermal processing $[10,11]$.

For prolonging storage terms of pasteurized sausage products, an influence of varying the chemical composition of recipes on safety parameters at storage has not been studied yet.

In most researches studies of the influence of regulators of oxidation processes are oriented on using natural antioxidants, oleoresins of spices and extracts, and that doesn't take into account their possible inactivation at pasteurization $[12,13]$. The use of active high-barrier package $[14,15]$, non-traditional methods of raw materials preparation $[16,17]$ are potential directions of further studies. But at using methods of increasing package barriers, more attention must be paid to reorientation of raw material resources on using poultry meat, vegetable fillers [18-20], milk processing products [21, 22], food hydrocolloids and emulsions [25]. Effective prognostication of storage terms of pasteurized sausages needs determining their influence on products safety parameters, namely microbiological contamination, lipids spoilage, creation of undesirable low-molecular compounds.

It is urgent to conduct a non-parametric analysis of MAFAM accumulation, kinetics of lipids spoilage at storage for sausages with an essential part of secondary animal raw materials [23, 24].

Boiled sausages belong to products with a high $a_{w}[26,27]$ that may cause moisture separation at storage alongside with microbiological spoilage [28]. An influence of non-bound water on lipids spoilage processes at using repeated pasteurization needs specification [29-31].

An influence of "active package" elements on lipids and microflora stability in pasteurized boiled sausage products at long-term storage has not been properly studied and parameterized [34].

That is why parametrization and obtaining of adequate dependencies of the influence of "active package" elements use at pasteurization on lipids spoilage resistance in boiled sausages at long storage terms need researches. 
Statistically reliable parametrization allows to prognosticate and substantiate rational storage terms of pasteurized boiled sausages of long-term storage.

\section{Research aim and tasks}

The research aim is to prognosticate storage terms of sausages, pasteurized using a sachet-package of an oxygen absorber.

The following tasks were set for attaining this aim:

- to plan the research matrix of important factors for estimating their influence on safety parameters of sausage products;

- to determine regressive dependencies of the influence of changeable factors on safety parameters of sausage products at storage;

- to determine the adequacy of regression equations for reproducing real and calculating values of safety parameters of small sausages at storage;

- to determine a possibility of storage terms prolongation for sausage products, pasteurized with an oxygen absorber according to reproduction results of real and calculating values of the content of sodium nitrite, peroxide, acid number and microbiological contamination level at storage.

\section{Materials and Methods}

For parametrizing safety indices of sausages, pasteurized with an oxygen absorber for longterm storage, there were used small sausages of the highest and first sort, produced at "Zhytomir meat-processing factory" LTD (Ukraine) by TC U 15.1-32122069-006:2008 [34].

The recipes of small sausages included pork, broiler chicken meat, beef, protein stabilizers, animal collagen-containing proteins and spices as raw materials [34].

Sausages, cooled to temperature $15^{\circ} \mathrm{C}$, were packed in multi-layer polymer films, produced by "Sirius Extrusion" LTD (Ukraine) with and without a sachet-package of an oxygen absorber at vacuum package with amount of an active substance 2.5 grams. The samples of sachet-packages of oxygen-absorbers were produced according to TC C 20.5-02070938-143:2013 "YUTAK" LTD (UKRAINE).

Packed sausages were pasteurized in a thermochamber by «Fessman» (Germany) at temperature 85-90 ${ }^{\circ} \mathrm{C}$ during $15-20$ minutes. After further cooling to temperature $15{ }^{\circ} \mathrm{C}$, packed small sausages were additionally cooled to a temperature from 0 to $6{ }^{\circ} \mathrm{C}$ and stored up to 95 days. At storage samples of sausages were selected according to the research plan, and microbiological parameters and residual content of nitrite were determined for them according to requirements of TC U 15.1-32122069-006:2008 by standard methods.

Microbiological parameters were determined by the horizontal method of microorganism calculation [31-33], according to SSU ISO 4833-2:2014 «Microbiology of food chain.»

For determining PN and AN, fat was removed. The small sausage batch was comminuted with water-free sodium sulphate and extracted by the infusion method. Solvers, provided by the correspondent method, are used for extraction. For determining AN, hot ethyl alcohol was used, for $\mathrm{PN}$ - the mixture of isooctane and icy acetic acid.

For determining AN, a batch of the fat solution was taken away to a conic flask of $250 \mathrm{~cm}^{3}$. The sample batch mass was determined depending on the expected value of acid number.

$50 \mathrm{~cm}^{3}$ of ethyl alcohol that contains $0.5 \mathrm{~cm}^{3}$ of phenolphthalein was heated to boiling in the second flask. At ethyl alcohol temperature $70{ }^{\circ} \mathrm{C}$, it was accurately neutralized by the potassium hydroxide solution. Titration was stopped if at adding one drop of alkaline, a hardly noticeable color change took place and didn't disappear during $15 \mathrm{~s}$. Neutralized ethyl alcohol was poured in the first flask with an experimental sample and accurately mixed. The content of the flask was boiled and titrated by the potassium hydroxide solution with the concentration $C=0.1 \mathrm{~mol} / \mathrm{dm}^{3}$ or $C=0.5 \mathrm{~mol} / \mathrm{dm}^{3}$ depending on the expected value of acid number, shaking the content of the flask at titration. The acid number was calculated by the formula:

$$
A N=5,611 \mathrm{VK} / \mathrm{m} \text {, }
$$


where 5,611 - titre of $0.1 \mathrm{~N}$ solution of potassium hydroxide, $\mathrm{mg} / \mathrm{ml} ; V$ - amount of $0.1 \mathrm{~N}$ alkaline solution, spent for titration, $\mathrm{ml} ; K$ - correction to the titre of the potassium hydroxide solution; $m$ - fat batch mass, g.

For determining PN, a fat batch of $1 \mathrm{~g}$ was weighted in a corked flask, and $10 \mathrm{~cm}^{3}$ of chloroform were added. The sample was dissolved, $15 \mathrm{~cm}^{3}$ of acetic acid and $1 \mathrm{~cm}^{3}$ of the iodine potassium solution was added. After that the flask was corked, the content was mixed during $1 \mathrm{~min}$ and left for $5 \mathrm{~min}$ in a dark place at temperature $15-25^{\circ} \mathrm{C}$. Then $75 \mathrm{~cm}^{3}$ of water were added, accurately mixed, and 5 drops of the starch solution were added. Two parallel measurings and control experience with the same reagents under the same conditions without fat were performed for each studied sample.

The peroxide number (in millimoles) was calculated by the formula:

$$
X=\left(V_{1}-V_{0}\right) \cdot C \cdot 1000 / m
$$

where, $V_{0}$ - volume of the sodium thiosulphate solution, used for titrating the control sample, $\mathrm{cm}^{3}$; $V_{1}$ - volume of the sodium thiosulphate solution, used for titrating the main sample, $\mathrm{cm}^{3} ; C-$ concentration of the sodium thiosulphate solution, $\mathrm{mol} / \mathrm{dm}^{3} ; m$ - batch of the studied sample, g; 1000 - calculating coefficient.

Thee- and fourfold repetition of the studied parameter was used for estimation in the research process. The reliable probability was $P=0.95$ for determining the statistical error.

The experimental data were modeled and processed by the mathematical package MathCad and "Data analysis" (ET) MS Excel.

For estimating the influence extent of each factor, included in the model, on the studied resulting parameters at the fixed middle level of other factors, the three-factor regression analysis of the experimental data was conducted.

An important condition was the absence of a functional connection between factors. The mathematic model was constructed as an analytic expression that determined a connection of factor signs with a parametrized index that is a response function was found. The equation of multiple regression for the experimental data of determination in the process of storage of the residual content of sodium nitrite, PN and AN values and also MAFAM changes may be expressed in linear form:

$$
Y\left(X_{1}, X_{2}, X_{3}\right)=b_{0}+b_{1} X_{1}+b_{2} X_{2}+b_{2} X_{3}+\varepsilon
$$

where, $b_{0}$ - free term that determines $Y$ value, when all independent variables of $X_{i}$ are equal to 0 .

$b_{1}, b_{2}$ - demonstrate how a resulting sign changes at changing each independent coded factor $X_{1}, X_{2}$ and $X_{3}$ by a measuring unit.

At determining parameters, changing factors were:

$C_{1}$ - storage time, days; $\left(C_{1 \min }=1 ; C_{1 \max }=94 ; C_{01}=47\right)$;

$C_{2}$ - starch part in the recipe of small sausages, $\% ;\left(C_{2 \min }=0 ; C_{2 \max }=3.15 ; C_{02}=1,575\right)$;

$C_{3}$ - presence of a sachet-package of an oxygen absorber at pasteurization with the net mass, $\mathrm{g}\left(C_{3 \min }=0 ; C_{3 \max }=2.5 ; C_{03}=1.25\right)$;

$Y_{1} ; Y_{2} ; Y_{3} ; Y_{4}$ - respectively residual content of the sodium nitrite, $\% ; \mathrm{AN}, \mathrm{KOH} / \mathrm{g}$ of fat; $\mathrm{PN}$, mmol AA; MAFAM CFU in $1 \mathrm{~g}$ in control storage points;

$\varepsilon$-occasional change, characterizing the deviation of $X_{1}, X_{2}$ and $X_{3}$ from the regression line (residual change).

For mathematical prognostication, there was the transition to coded numbers, system graphics of the plan were developed and realized.

$X_{1}$ is a coded variable that determines storage time of packed units of the products after pasteurization ( $X_{1}=-1$ for the first day; $X_{1}=+1$ at the end of storage for 94 day). $X_{1}$ value in the middle of the plan approaches to the normatively recommended storage time of pasteurized sausages that is 45 days.

$X_{2}$ is a coded variable that determines the starch percent in the forcemeat mass of small sausages $\left(X_{2}=-1\right.$ for small sausages of the highest sort the starch share is equal to null; $X_{1}=+1$ at $3.15 \%$ 
of starch in forcemeat of small sausages, determined by the normative limitations of the starch share in small sausages of the first sort).

$X_{3}$ is a coded variable that determines the net mass of the oxygen absorber mixture in a sachet-package $\left(X_{3}=-1\right.$ for small sausages, pasteurized without an oxygen absorber; $X_{1}=+1$ for small sausages, pasteurized with a sachet-package of an oxygen absorber with net content of an active substance in it $2.5 \mathrm{~g}$ ).

The mathematical expectation of the occasional deviation of $\varepsilon_{\mathrm{i}}$ is equal to 0 for all observations $\left(M\left(\varepsilon_{i}\right)=0\right)$.

For estimating unknown parameters $b_{0}, b_{1}, b_{2}$, the method of least squares (MLS) was used. According to it, unknown parameters of a function are chosen in such a way that the sum of deviation squares of experimental (empirical) values of $Y_{i}$ from their calculating (theoretical) $Y_{\check{\partial}}$ values is minimal that is:

$$
S=\sum_{i=1}^{n}\left(Y_{\tilde{\delta}}-Y_{i}\right)^{2}=\sum_{i=1}^{n}\left(Y-\phi\left(X, b_{0}, b_{1 \varkappa \ldots, b}\right)\right)^{2} \rightarrow \min .
$$
in Table 1.

The planning matrix of the complete factor experiment for three factors is presented

Table 1

The planning matrix of the complete factor experiment for three factors

\begin{tabular}{|c|c|c|c|c|c|c|}
\hline \multirow{2}{*}{$\begin{array}{c}\text { Experiment } \\
\text { number }\end{array}$} & \multicolumn{3}{|c|}{ Plan in coded variables } & \multicolumn{3}{|c|}{ Real values of changing factors in experiments } \\
\hline & $\mathrm{X}_{1}$ & $\mathbf{X}_{2}$ & $\mathbf{X}_{3}$ & $\mathrm{C}_{1}$, days & $\mathrm{C}_{2}, \%$ & $\mathrm{C}_{3}, \mathrm{~g}$ \\
\hline 1 & -1 & -1 & -1 & 1 & 0 & 0 \\
\hline 2 & -1 & +1 & -1 & 1 & 3.12 & 0 \\
\hline 3 & -1 & -1 & +1 & 1 & 0 & 2.5 \\
\hline 4 & -1 & +1 & +1 & 1 & 3.15 & 2.5 \\
\hline 5 & -0.35 & -1 & -1 & 35 & 0 & 0 \\
\hline 6 & -0.35 & +1 & -1 & 35 & 3.12 & 0 \\
\hline 7 & -0.35 & -1 & +1 & 35 & 0 & 2.5 \\
\hline 8 & -0.35 & +1 & +1 & 35 & 3.15 & 2.5 \\
\hline 9 & +0.35 & -1 & -1 & 65 & 0 & 0 \\
\hline 10 & +0.35 & +1 & -1 & 65 & 3.12 & 0 \\
\hline 11 & +0.35 & -1 & +1 & 65 & 0 & 2.5 \\
\hline 12 & +0.35 & +1 & +1 & 65 & 3.15 & 2.5 \\
\hline 13 & +1 & -1 & -1 & 94 & 0 & 0 \\
\hline 14 & +1 & +1 & -1 & 94 & 3.12 & 0 \\
\hline 15 & +1 & -1 & +1 & 94 & 0 & 2.5 \\
\hline 16 & +1 & +1 & +1 & 94 & 3.15 & 2.5 \\
\hline
\end{tabular}

According to the research matrix, changes of the critically important safety parameters of small sausages in time by the obtained values of residual sodium nitrite $\left(Y_{1}, \%\right)$, AN value $\left(Y_{2}, \mathrm{KOH} / \mathrm{g}\right.$ of fat), PN value $\left(Y_{3}, \mathrm{mmol} \mathrm{AA}\right)$, MAFAM values $\left(Y_{4}, \mathrm{CFUin} 1 \mathrm{~g}\right.$ of the product $)$ in control storage points were conducted at the whole storage time.

Control time intervals in the studies of the critically important safety parameters were the first, 35, 65 and 94 days of storage.

At that the null time level was approximated to 45 days that normatively regulates the storage time of pasteurized small sausages. 


\section{Results}

According to the obtained results with using modeling and experimental data processing, using the mathematical package MathCad and "Data analysis" (ET) MSExcel, regression equations that adequately describe correspondent dependencies between changing factors and response function were calculated.

The adequacy of models was verified by determination coefficients $R_{Y 1}^{2}=96 \%$, $R_{Y 2}^{2}=98 \%, R_{Y 3}^{2}=93 \%, R_{Y 4}^{2}=91 \%, R_{Y 5}^{2}=99 \%$ and $R_{Y 6}^{2}=98 \%$ that testifies to the high quality characteristics of the connection of system coefficients. Verification using F-test (F-Fisher criterion) and Student t-distribution for estimating the reliability of correlation coefficients was realized.

The dependence of the residual content of nitrite $\left(Y_{1}, \%\right)$ in small sausages at storage on changing factors is described by equation 5 .

$$
Y_{1}=0.0028-0.00001 X_{1}-0.00003 X_{2}+0.001 X_{3} \text {. }
$$

This reproduction adequacy is visually traced in Fig. 1.

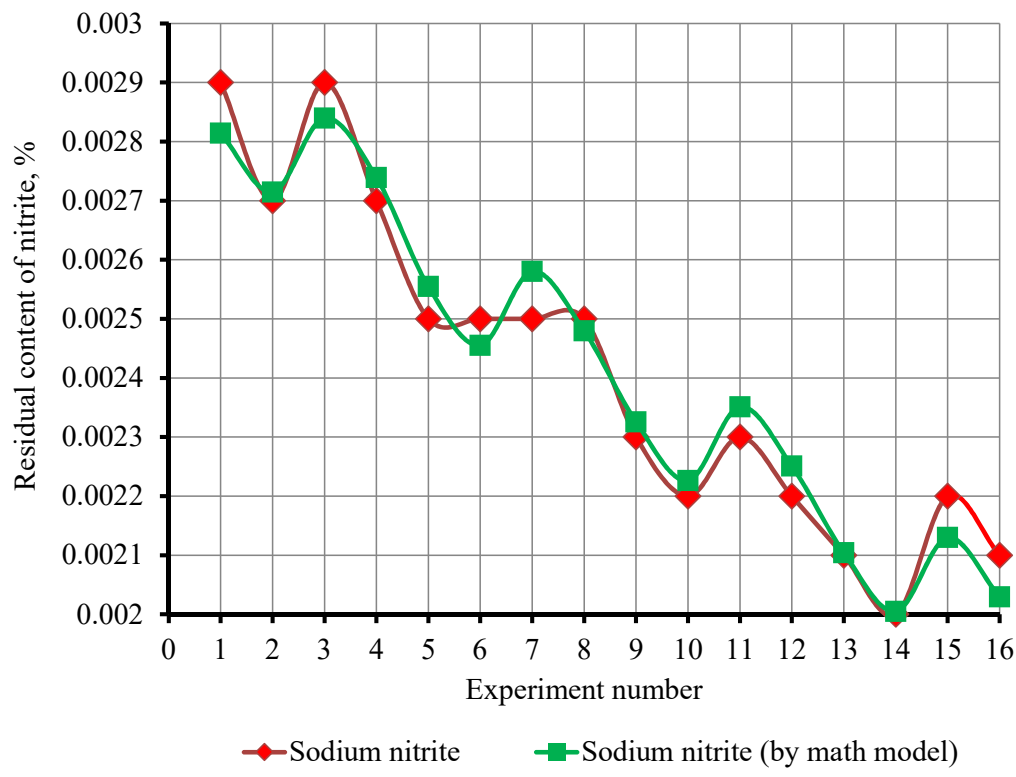

Fig. 1. Reproduction of real and calculating values of the residual content of sodium nitrite in pasteurized small sausages at storage

Equation 6 describes the quantitative ratio of $Y_{2}, \mathrm{AN} \mathrm{mg,} \mathrm{KOH} / \mathrm{g}$ of fat:

$$
Y_{2}=0.96+0,04 \cdot X_{1}-0,57 \cdot X_{2}+3,4 \cdot X_{3} \text {. }
$$

This reproduction adequacy is visually traced in Fig. 2.

Equation (7) describes the change in time, PN, mmol AA $\left(Y_{3}\right)$ :

$$
Y_{3}=-0,47+0,1 \cdot X_{1}-0,66 \cdot X_{2}+7,25 \cdot X_{3} \text {. }
$$

This adequacy is visually traced in Fig. 3.

Equation 8 describes values of MAFAM, CFU in $1 \mathrm{~g},\left(Y_{4}\right)$ :

$$
Y_{4}=91,81+1,09 \cdot X_{1}-3,66 \cdot X_{2}-426,28 \cdot X_{3} .
$$

This reproduction adequacy is visually traced in Fig. 4. 


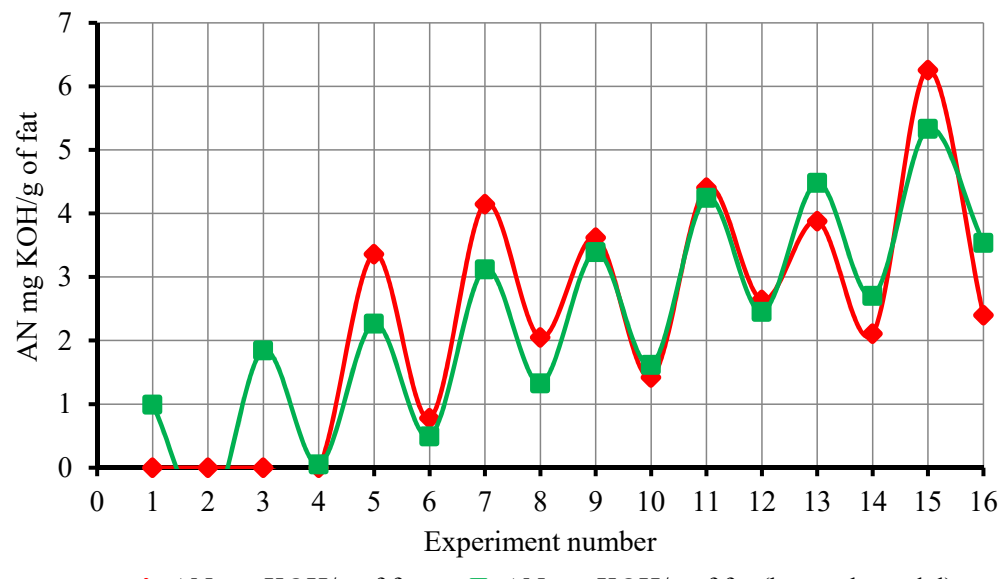

AN mg KOH/g of fat $\quad-\mathrm{AN} \mathrm{mg} \mathrm{KOH} / \mathrm{g}$ of fat (by math model)

Fig. 2. Reproduction of real and calculating values of acid number (AN) in pasteurized small sausages at storage

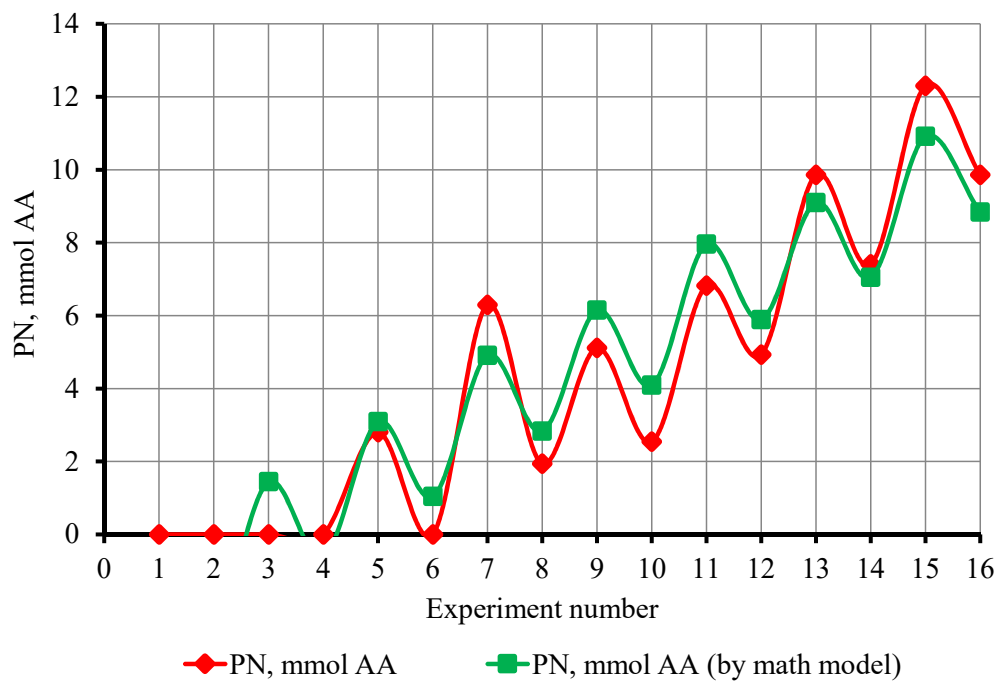

Fig. 3. Reproduction of real and calculating values of peroxide number (PN) in pasteurized small sausages at storage

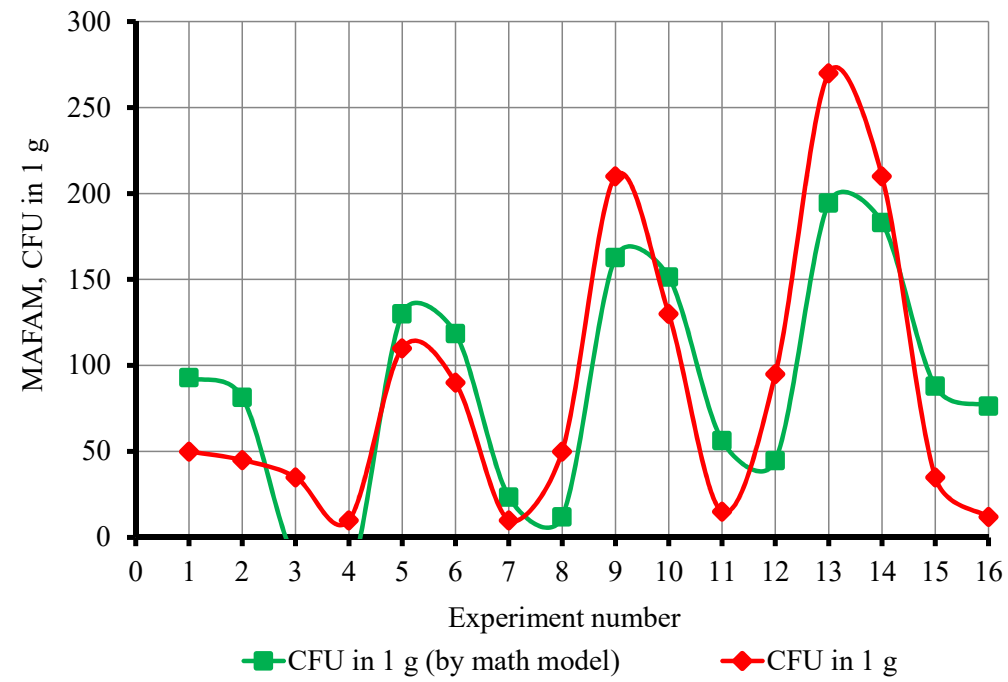

Fig. 4. Reproduction of real and calculating values of MAFAM and CFU in $1 \mathrm{~g}$ in pasteurized small sausages at storage 
In the process of storage of pasteurized boiled sausage products the share of sodium nitrite decreases that may be connected with the increase of PN values at storage.

For revealing the dependence of the change of sodium nitrite on PN, the response function was calculated by the totality of mathematic and statistic methods for finding combinations of experimental series of predicators for constructing a response surface.

In general form the response function is described by the following polynomial:

$$
\hat{y}(x, b)=b_{0}+\sum_{l=1}^{n} b_{l} x_{l}+\sum_{k=1}^{n} b_{k} x_{k}^{2}+\sum_{i=1}^{n-1} \sum_{j=i+1}^{n} b_{i j} x_{i} x_{j},
$$

where $x \in R^{n}$ - vector of variables, $b$ - vector of parameters.

For modeling residual sodium nitrite, response functions as polynomials of the second order were chosen.

$$
Y_{\mathrm{NaNO}_{2}}=b_{0}+b_{1} \tau+b_{11} \tau^{2}+b_{2} \mathrm{PN}+b_{22} \mathrm{PN}^{2}+b_{12} \tau \mathrm{PN},
$$

where $b$ - constant; $\tau$ - time, days; PN - peroxide number, $(\mathrm{PN}, \mathrm{mmol} A \mathrm{~A}), Y_{\mathrm{NaNO}_{2}}-$ residual sodium nitrite, $\%$.

For verifying the adequacy of the obtained dependencies, a mean square deviation was calculated as a square root of dispersion by the formula:

$$
\sigma=\sqrt{\frac{\sum_{i=1}^{n}\left(y_{i}-\hat{y}_{i}\right)^{2}}{n-1}}
$$

where $\hat{y}_{3}$ - values, calculated by the regression equation, $y_{i}-$ values of the experimental data.

For residual nitrite of pasteurized sausages $\sigma=0.00001 \%$ that testifies to rather high reproduction level of the research results of safety parameters values of pasteurized sausages.

The analysis of the presented results testifies that repeated pasteurization provides enough microbiological stability of sausages without using an oxygen absorber.

At using an oxygen oxidizer at the stage of pasteurization the microbiological stability is higher that allows to prognosticate by the MAFAM index potentially much more storage term of highest sort small sausages. The residual nitrite decrease at storage is corrected with increasing PN value. The analysis of AN and PN changes dynamics indicates potentially more negative influence of lipids oxidation processes compared to ones of lipids hydrolysis at small sausages storage.

Thus, for substantiating the storage term of sausage products, it is necessary to prognosticate and control the process of lipids oxidation by PN values together with MAFAM control.

\section{Conclusions}

According to the analysis of recommended storage terms of pasteurized sausages and presence of starch in their recipes, the research matrix of the influence of pasteurization with a sachet-package with an oxygen absorber on small sausages' safety parameters at storage has been planned.

The regression parametrization has been conducted that allowed to determine the influence dependencies of changing factors on indices of the residual content of sodium nitrite, peroxide, acid number and MAFAM values at storage.

The statistically reliable adequacy of the regression equation has been confirmed by reproduction of real and calculating values of the residual content of sodium nitrite, peroxide, acid number sausages and microbiological parameters in pasteurized small at storage. The obtained empirical dependencies allow to prognosticate the storage term of boiled sausage products, pasteurized with an oxygen absorber at using protecting barrier multi-layer polymer materials.

According to the regression equations it has been determined, that the use of an oxygen absorber at the pasteurization stage allows to increase the microbiological stability of sausage 
products and to prognosticate the higher storage term of highest sort small sausages than the one, regulated by MAFAM index. The assessment of residual nitrite changes dynamics at storage is corrected with PN values increase.

It has been confirmed, that for substantiating the storage term of sausage products, it is necessary to prognosticate and control the process of lipids oxidation by PN values together with MAFAM control.

\section{References}

[1] Klymenko, M. M., Vinnikova, L. H., Bereza, I. H. et. al.; Klymenko, M. M. (Ed.) (2006). Tekhnolohiya miasa ta miasnykh produktiv. Kyiv: Vyshcha osvita, 640.

[2] Bal-Prylypko, L. V. (2010). Tekhnolohiya zberihannia, konservuvannia ta pererobky miasa. Kyiv, 469.

[3] Bozhko, N., Tischenko, V., Pasichnyi, V., Marynin, A., Polumbryk, M. (2017). Study of oxidation processes in duck meat with application of rosemary and grape seed extracts. EUREKA: Life Sciences, 4, 10-15. doi: https://doi.org/10.21303/25045695.2017.00374

[4] Pasichnyi, V. M., Heredchuk, A. M., Moroz, O. O., Yastreba, Yu. A. (2015). Doslidzhennia faktoriv prolonhatsiyi terminiv zberihannia miasnykh ta miasomistkykh produktiv. Naukovi pratsi NUKhT, 21 (4), 224-230.

[5] Robertson, G. L.( 2012.) Food Packaging: Principles and Practice. CRC Press. doi: https://doi.org/10.1201/9781420056150

[6] Lee, J. J., Kim, D. H., Lim, J. J., Kim, D. G. et. al. (2011). Sterilization effects of avian influenza virus and newcastle disease virus in chicken muscle and organs dependent on autoclaving time. Korean Journal of Veterinary Public Health, 35 (4), $270-274$. Available at: http://agris.fao.org/agris-search/search.do?recordID=KR2012004468

[7] Silva, F. V. M., Gibbs, P. A. (2012). Thermal pasteurization requirements for the inactivation of Salmonella in foods. Food Research International, 45 (2), 695-699. doi: https://doi.org/10.1016/j.foodres.2011.06.018

[8] Bal'-Prilipko, L. V., Zadorozhnyy, V. I., Onishchenko, L. V. (2006). Vliyanie razlichnyh faktorov na srok i kachestvo hraneniya myasnyh produktov. Myasnoe delo, 8, 53-55.

[9] Shahidi, F. (Ed.) (1997). Natural Antioxidants. Chemistry, Health Effects and Applications. Champaign: AOCS Press, 432.

[10] Pasichnyi, V. M., Khrapachov, O. V., Ukrainets, A. I., Marynin, A. I., Lohvynenko, N. P., Kapitula, E. I. (2018).Use of repeated pasteurization for the production of boiled sausage products. Scientific Messenger of LNU of Veterinary Medicine and Biotechnologies. Series «Food Technologies», 20 (85), 29-34. doi: https://doi.org/10.15421/nvlvet8506

[11] Ukrainets, A., Pasichniy, V., Zheludenko, Yu., Zadkova, S. (2016). Oleoresins effect on cooked poultry sausages microbiological stability. Ukrainian Food Journal, 5 (1), 124-134.

[12] Ukrainets, A., Pasichny, V., Zheludenko, Yu. (2016). Antioxidant plant extracts in the meat processing industry. Biotechnologia Acta, 2, 19-27. doi: https://doi.org/10.15407/biotech9.02.019

[13] McBride, N. T. M., Hogan, S. A., Kerry, J. P. (2007). Comparative addition of rosemary extract and additives on sensory and antioxidant properties of retail packaged beef. International Journal of Food Science \& Technology, 42 (10), $1201-1207$. doi: https://doi.org/10.1111/j.1365-2621.2006.01342.x

[14] Dixon, J. (2011). Packaging Materials 9: Multilayer Packaging for Food and Beverages. ILSI, 48. Available at: http://ilsi.eu/ wp-content/uploads/sites/3/2016/06/ILSI-11-011-9-pack-03.pdf

[15] Pasichnyi, V., Ukrainets, A., Khrapachov, O., Marynin, A. (2018). MAIN aspects of using multilayer polymeric materials for pasterization and sterilization of products in the meat processing industry. Scientific Works of National University of Food Technologies, 24 (4), 195-203. doi: https://doi.org/10.24263/2225-2924-2018-24-4-22

[16] Vinnikova, L., Prokopenko, I. (2015). The application of high pressure as an alternative to thermal processing of poultry meat. Eastern-European Journal of Enterprise Technologies, 3 (10 (75)), 31-36. doi: https://doi.org/10.15587/17294061.2015.44241

[17] Dubkovetskyy, I., Strashinsky, I., Strelchenko, L., Kolomiez, R. (2015). Study of convective-infrared drying changes in the characteristics of protein preparations of animal and vegetable. Zbirnyk naukovykh prats Vinnytskoho natsionalnoho ahrarnoho universytetu. Seriya: Tekhnichni nauky, 1 (2), 55-61.

[18] Mohammed, H. N. (2013). Study of some chemical, physical, sensory and bacteriology characteristics of canned chicken meat imported to Sulaymaniyah markets, Iraq. International Journal of nutrition and Metabolism, 5 (7), 128-133.

[19] Kotlyar, Y., Topchiy, O. (2017). Development of recipeurs of meat pieces with the use of protein-fatty emulsions based on vitaminized blended vegetable oils. Scientific Messenger of LNU of Veterinary Medicine and Biotechnologies, 19 (75), 89-96. doi: https://doi.org/10.15421/nvlvet7518

[20] Rinok m'yasa ptitsi v Ukrayini (2017). Available at: http://www.poultryukraine.com/data/file/analytics/ptica_yanvar_ maj_2017.pdf 
[21] Svyatnenko, R., Marynin, A., Kochubej-Litvinenko, O., Zakharevych, V. (2016). Impact of pulsed electromagnetic field on escherichia coli vitality in model solution of milk serum. Scientific Messenger of LNU of Veterinary Medicine and Biotechnologies, 18 (2), 92-94. doi: https://doi.org/10.15421/nvlvet6818

[22] Ukrainets, A., Kochubei-Lytvynenko, O., Bilyk, O., Zakharevych, V., Vasylchenko, T. (2016). A study of the effect of enriched whey powder on the quality of a special-purpose bread. Eastern-European Journal of Enterprise Technologies, 2 (11 (80)), 32-41. doi: https://doi.org/10.15587/1729-4061.2016.65778

[23] Kishen'ko, I. I., Kryzhova, Yu. P., Donets, A. P., Topchiy, O. A. (2014). Production of the restructured ham products w ith use of the proteinfatty emuusion. The Journal of Almaty Technological University, 4, 48-54.

[24] Kishenko, I. I., Kryzhova, Y. P., Linkevich, M. V., Krupska, A. A. (2015). The use of albuminous preparations of animal origin is in technology of hams. Scientific Messenger of LNU of Veterinary Medicine and Biotechnologies, 17 (4), 54-59.

[25] Pasichnyi, V. M., Marynin, A. I., Moroz, O. O., Heredchuk, A. M. (2015). Development of combined protein-fat emulsions for sausage and semifinished products with poultry meat. Eastern-European Journal of Enterprise Technologies, 1 (6 (73)), 32-38. doi: https://doi.org/10.15587/1729-4061.2015.36232

[26] Usatenko, N. F., Kryzhska, T. A. (2012). Zberihannia ta pererobka produktsiyi. Vykorystannia pokaznyka «aktyvnist vody» v tekhnolohiyi vyrobnytstva miasoproduktiv. Visnyk ahrarnoi nauky, 5, 62-65.

[27] Benderska, O., Levkivska, T., Bessarab, A. (2018). Technological aspects of «water activity» indicator and its influence on the quality of tomato souss. International scientific journal Internauka. Available at: https://www.inter-nauka.com/uploads/ public/15278745764128.pdf

[28] Shubina, G. (2015). Vydelenie vlagi v upakovkah gotovyh myasnyh produktov: prichiny i puti resheniya problemy. Myasnoy biznes, 2, 26-28.

[29] TU U 15.1-31923621-002:2010. Vyroby kovbasni vareni, sosysky, sardelky, zapakovani pid vakuumom v polimerni bahatosharovi materialy «Kriovak» («CRYOVAC») pasteryzovani.

[30] TU U 563/46.05407953.60-98. Vyroby kovbasni ta kopchenosti miasni, zapakovani pid vakuumom v polimerni plivkovi bahatosharovi termozsidalni materialy «Kriovak» («CRYOVAC»).

[31] DSTU 8446:2015. Produkty kharchovi. Metody vyznachennia kilkosti mezofilnykh aerobnykh ta fakultatyvno-anaerobnykh mikroorhanizmiv (2015). Kyiv, 16.

[32] Antipova, L. V., Glotova, I. A., Rogov, I. A. (2001). Metody issledovaniya myasa i myasnyh produktov. Moscow: Kolos, 576.

[33] DSTU ISO 4833:2006. Horyzontalnyi metod pidrakhunku mikroorhanizmiv. Tekhnika pidrakhuvannia koloniy za temperatury $30{ }^{\circ} \mathrm{C}$ (ISO 4833:2003, IDT) (2008). Kyiv, 7.

[34] Pasichnyi, V., Ukrainets, A., Ukrainets, A., Khrapachov, O., Khrapachov, O., Marynin, A. et. al. (2018). Research into efficiency of pasterization of boiled sausage products in order to improve their storage term. Eastern-European Journal of Enterprise Technologies, 6 (11 (96)), 21-28. doi: https://doi.org/10.15587/1729-4061.2018.147946 